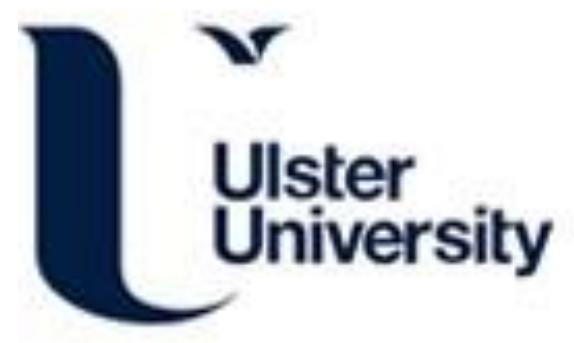

\title{
TOFSIMS and XPS characterisation of strontium in amorphous calcium phosphate sputter deposited coatings
}

Acheson, J., Robinson, L., McKillop, S., Wilson, S., Morton, J., Meenan, BJ., \& Boyd, A. (2021). TOFSIMS and XPS characterisation of strontium in amorphous calcium phosphate sputter deposited coatings. Materials Characterization, 171, [110739]. https://doi.org/10.1016/j.matchar.2020.110739

Link to publication record in Ulster University Research Portal

\section{Published in:}

Materials Characterization

Publication Status:

Published (in print/issue): 01/01/2021

DOI:

10.1016/j.matchar.2020.110739

\section{Document Version}

Author Accepted version

\section{General rights}

Copyright for the publications made accessible via Ulster University's Research Portal is retained by the author(s) and / or other copyright owners and it is a condition of accessing these publications that users recognise and abide by the legal requirements associated with these rights.

\section{Take down policy}

The Research Portal is Ulster University's institutional repository that provides access to Ulster's research outputs. Every effort has been made to ensure that content in the Research Portal does not infringe any person's rights, or applicable UK laws. If you discover content in the Research Portal that you believe breaches copyright or violates any law, please contact pure-support@ulster.ac.uk. 
Title: TOFSIMS and XPS Characterisation of Strontium in Amorphous Calcium Phosphate Sputter Deposited Coatings

Authors: J.G. Acheson, L. Robinson, S. McKillop, S. Wilson, M.J. Morton, B.J. Meenan and A.R. Boyd*

Affiliation: Nanotechnology and Integrated Bioengineering Centre (NIBEC), School of Engineering, University of Ulster, Shore Road, Newtownabbey, Co. Antrim, BT37 0QB. Northern Ireland (UK).

* - Corresponding Author:

Dr. Adrian Boyd

Nanotechnology and Integrated Bioengineering Centre (NIBEC),

School of Engineering,

Ulster University,

Shore Road, Newtownabbey,

Co. Antrim, BT37 0QB.

Northern Ireland (UK).

Tel: $+44(0) 2890368924$

E-mail: ar.boyd@ulster.ac.uk 


\begin{abstract}
Strontium $(\mathrm{Sr})$ substituted calcium phosphate $(\mathrm{CaP})$ coatings have stimulated a lot of interest as $\mathrm{Sr}$ is known to provide osteoconductive properties. Most of the work to date with respect to $\mathrm{Sr}$ substituted coatings has focused on the creation of crystalline Srsubstituted hydroxyapatite (HA), as opposed to amorphous coatings. The work reported here utilises radio frequency magnetron sputtering to deposit both amorphous $\mathrm{CaP}$ and Sr-containing $\mathrm{CaP}$ coatings and their characterisation using X-Ray Photoelectron Spectroscopy (XPS) and Time-of-Flight Secondary Ion Mass Spectrometry (ToF-SIMS). The CaP coating had a high $\mathrm{Ca} / \mathrm{P}$ atomic ratio at $1.81 \pm$ 0.02. The amorphous $\mathrm{Sr}$ containing $\mathrm{CaP}$ coating was shown to contain $\mathrm{Sr}$ with a $\mathrm{Ca} / \mathrm{P}$ and $(\mathrm{Ca}+\mathrm{Sr}) / \mathrm{P}$ atomic ratios of $1.18 \pm 0.05$ and $1.49 \pm 0.05$, respectively. Peak-fitting of the overlapping $\mathrm{Sr} 3 \mathrm{~d}$ and $\mathrm{P} 2 \mathrm{p}$ region also showed the presence of previously unreported doublets for each element. The ToF-SIMS results also highlighted that $\mathrm{Sr}$ was homogeneously distributed across the surface of the Sr containing coating via detailed chemical mapping experiments. This study has shown that sputtering can be used to deposit Sr-containing $\mathrm{CaP}$ coatings and that the use of surface analytical techniqes is important for understanding their uppermost surface properties.
\end{abstract}

Keywords: strontium, amorphous calcium phosphate, ToF-SIMS, XPS, RF magnetron sputtering 


\subsection{Introduction}

Hydroxyapatite $\left[\mathrm{HA}-\mathrm{Ca}_{10}\left(\mathrm{PO}_{4}\right)_{6}(\mathrm{OH})_{2}\right]$ is a calcium phosphate $(\mathrm{CaP})$ material that has been extensively studied a bulk material for replacement of human bone tissue and as coatings on orthopaedic devices due to their similarity to the inorganic portion of human bone. However, it is well understood that biological apatites differ significantly from the chemically pure forms of laboratory synthesised CaPs. Typically, biological apatite has a $\mathrm{Ca} / \mathrm{P}$ of around 1.54 , which is significantly lower than chemically pure HA [1]. It has also been shown to contain a range of trace ions, including strontium $(\mathrm{Sr})$, magnesium $(\mathrm{Mg})$, silicon $(\mathrm{Si})$ and zinc $(\mathrm{Zn})$ as highlighted in Table $1[2,3]$. Therefore, in order to enhance the performance of $\mathrm{CaP}$ coatings used in orthopaedic implant devices, it is suggested the development of substituted $\mathrm{CaP}$ materials for such applications is a priority given the positive benefits such materials could provide.

Table 1. Comparison of the composition and lattice parameters of the mineral phase of bone with stoichiometric HA [2,3].

\begin{tabular}{llll}
\hline Composition & Conc. level & Bone & Stoichiometric HA \\
\hline Calcium $(\mathrm{Ca})$ & wt. \% & $34.8-36.6$ & 39.6 \\
Phosphorus $(\mathrm{P})$ & & $15.2-17.1$ & 18.5 \\
Carbonate $\left(\mathrm{CO}_{3}\right)$ & & - \\
Sodium $(\mathrm{Na})$ & & $0.90-1.00$ & - \\
Magnesium $(\mathrm{Mg})$ & & $0.60-0.72$ & - \\
Chlorine $(\mathrm{Cl})$ & $0.10-0.13$ & - \\
Fluorine $(\mathrm{Fl})$ & $0.10-0.03$ & - \\
Potassium $(\mathrm{K})$ & $0.03-0.07$ & - \\
Strontium $(\mathrm{Sr})$ & & $0-0.05$ & - \\
Silicon $(\mathrm{Si})$ & $0-500$ & - \\
Zinc $(\mathrm{Zn})$ & $\mathrm{ppm}$ & $0-39$ & - \\
Chromium $(\mathrm{Cr})$ & & $0-0.33$ & - \\
Cobalt $(\mathrm{Co})$ & $0-0.025$ & - \\
Manganese $(\mathrm{Mn})$ & $0-0.17$ & - \\
\hline Lattice parameters & & Bone & Stoichiometric HA \\
\hline a-axis & 0.9410 & 0.9430 \\
c-axis & 0.6890 & 0.6891 \\
\hline
\end{tabular}


Of the trace elements highlighted in Table 1, Sr has been documented as beneficial as it plays a vital role in improving solubility, increasing bone formation via the stimulation of osteoblast activity, as well as enhancing pre-osteoblast proliferation and differentiation pathways down the osteoblast lineage [4]. Sr is also documented as having the ability to play an inhibiting role in the resorption of bone and encouraging new bone growth, potentially helping in the treatment of osteoporosis and improving bone strength [5-8]. In addition, there is still disagreement as to the preferred concentration of $\mathrm{Sr}$ in any substituted apatite in order to achieve the desired outcome, in vivo $[9,10]$. Therefore, to deliver the appropriate biofunctionality of the coatings produced it will be essential to regulate the levels of $\mathrm{Sr}$ available at the interface between the surface and the in vivo environment.

Sr substituted $\mathrm{CaP}$ coatings have already been manufactured using a range of wellestablished approaches, namely plasma spraying [11-13], sol-gel methods [14], pulsed laser deposition [15,16], micro-arc oxidation [17], co-blasting [18] and Radio Frequency (RF) Magnetron Sputtering methods [19-25]. Each techniques has advantages and disadvantages, but sputtering has already shown significant promise in this area as the operating parameters can be tuned to deliver coatings with specific properties. [19-25].

There is still a strong interest in developing and studying Sr substituted CaP coatings that could have the ability to enhance the osteoblast response. A core requirement in the development of such coatings is providing a detailed understanding of their uppermost surface properties [26-28]. Most studies to date provide a detailed characterisation of the bulk properties of coatings however, this can sometimes lead to misinterpretation of the interfacial relationship between the coating properties and its subsequent performance in physiological environments, which is critical [27]. There is therefore a requirement to undertake a detailed characterisation of the surface properties of any coatings produced, namely its chemistry that will be critical in determining its fate, both in vitro and ultimately, in vivo. To date, there are limited studies using surface characterisation techniques, such as those based on X-Ray Photoelectron Spectroscopy (XPS) and in particular Time-of-Flight Secondary Ion Mass Spectrometry (ToF-SIMS) to determine the uppermost surface chemistry of $\mathrm{Sr}$ substituted CaP [22,29]. Most notably, no studies have considered the spatial 
arrangement of the chemical species across the surface. Key to this work is the identification of the Sr species on the surface of the coatings.

In order to address this obvious deficiency, the work reported here details the deposition of amorphous $\mathrm{CaP}$ coatings containing $\mathrm{Sr}$ via $\mathrm{RF}$ magnetron sputtering and their subsequent detailed characterisation using XPS and ToF-SIMS in order to better understand their uppermost surface chemistry. In particular, ToF-SIMS is useful for this purpose as it provides high spatial resolution and allows chemical mapping of the distribution of chemical species at the surface [30]. Sr containing coatings in this study were deposited using established parameters of RF power, working gas pressure and throw distance in order to deliver amorphous coatings as has been previously undertaken by the authors [20-22,31-33]. The coatings produced here were characterised in the as-deposited state. The as-deposited state was chosen here, as they would be amorphous in nature, with such coatings highlighted as providing excellent reactivity and potential osteoconductivity in the physiological environment [34]. In

addition, the precursor powders used to produce the sputtering targets were also characterised to ensure their quality prior to deposition and to provide a benchmark for the coatings produced thereof. To the knowledge of the authors, this is the first attempt to undertake such a detailed characterisation of amorphous $\mathrm{CaP}$ sputter deposited coatings incorporating $\mathrm{Sr}$ ions using ToF-SIMS chemical mapping in conjunction with supporting detailed XPS analyses.

\subsection{Materials and Methods}

\subsection{Manufacturing of Sputtering Targets}

Sputtering targets were manufactured by dry pressing the precursor powder materials (hydroxyapatite [HA - (Plasma Biotal Captal-R), UK] powder or $13 \%$ biphasic calcium phosphate [SrHA - (Himed Inc. NY), USA]) into low oxygen copper troughs (76 mm diameter and $5 \mathrm{~mm}$ thick) at a load of $40 \mathrm{kN}$ for 10 minutes. Two sputtering targets were utilised for each deposition run. 


\subsection{Substrate Preparation}

Chemically pure titanium coupons (cpTi) [Titanium International Ltd., UK] were prepared by an established protocol in order to provide suitable surfaces onto which HA and SrHA coatings were deposited. [20-22].

\subsection{RF Magnetron sputter deposition}

Radio Frequency (RF) magnetron sputtering was undertaken using a Kurt J. Lester system (USA) as in previous published work [20-22].

\subsection{Characterisation of the Powders and Coatings}

The HA and SrHA powders were characterised using Raman Spectroscopy, Fourier Transform Infrared Spectroscopy (FTIR), X-Ray Diffraction (XRD), X-Ray Photoelectron Spectroscopy (XPS) and Time-of-Flight Secondary Ion Mass Spectrometry (ToF-SIMS). For the analysis of the powders using XPS and ToF-SIMS, the materials were pressed into a $13 \mathrm{~mm}$ disk to prevent loose powder contamination within the vacuum chambers. The as-deposited HA and SrHA coatings were characterised using both XPS and ToF-SIMS in order to determine the chemistry of the uppermost surface of the coatings. The coatings were only examined in the asdeposited state and were not subject to any thermal processing in order to maintain their amorphous nature.

XRD of the samples was carried out using a Bruker D8 Discover Diffractometer (Bruker, USA). Diffraction scans were obtained using a $\mathrm{Cu} K \alpha \mathrm{X}$-ray radiation $(\lambda=$ $1.540 \AA$ A) source, operating at $40 \mathrm{kV}$ and $40 \mathrm{~mA}$. FTIR spectroscopy scans were obtained for each sample using a Varian 640-IR system with a PIKE Diffuse Reflectance Infrared Fourier Transform Spectroscopy (DRIFTS) accessory in absorbance mode. Raman Spectroscopy of the samples was undertaken using an InVia Qontor Raman system (Renishaw, UK). Samples were analysed using a $785 \mathrm{~nm}$ laser and a x20 objective lens. XPS was performed using an Axis Ultra DLD Spectrometer (Kratos, UK). Spectra were analysed using monochromated Al Ka X-rays (hv = 1486.6 electron volts $(\mathrm{eV})$ ) operating at $10 \mathrm{kV}$ and $15 \mathrm{~mA}$. All high-resolution spectra for $\mathrm{C} 1 \mathrm{~s}, \mathrm{O} 1 \mathrm{~s}, \mathrm{Ca} 2 \mathrm{p}, \mathrm{P} 2 \mathrm{p} / \mathrm{Sr} 3 \mathrm{~d}, \mathrm{Sr} 3 \mathrm{p}$ and $\mathrm{P} 2 \mathrm{~s}$ were recorded at a pass energy of $20 \mathrm{eV}$. Sample charging was corrected by setting the lowest BE component of the $\mathrm{C} 1 \mathrm{~s}$ spectral envelope to $285.0 \mathrm{eV}$ [35]. Photoelectron spectra were further processed by 
subtracting a Tougaard background and using the peak area for the most intense spectral line of each detected elemental species to determine the $\%$ atomic concentration. In the case of the $\mathrm{Sr}$ substituted samples, the $\mathrm{P} 2 \mathrm{p}$ and $\mathrm{Sr} 3 \mathrm{~d}$ peaks overlap at $133.134 \mathrm{eV}$ therefore, for these samples the P2s and Sr3p peaks were used in order to provide the appropriate quantification results. In total 3 areas were analysed from each sample. Peak-fitting was carried out using a mixed Gaussian - Lorentzian synthetic peak function using Casa software (version 2.3.19PR1.0) (Casa Software Ltd., UK). Time-of-Flight Secondary Ion Mass Spectrometry (ToF-SIMS) data was obtained using a ToF-SIMS V instrument (IONTOF, Germany) equipped with a 25 $\mathrm{keV}$ bismuth (Bi) liquid metal ion gun (primary ion source) with an emission current of $1 \mu \mathrm{A}$, a pulsed target current of 14 nano Amps (nA). A pressure of at least $5.00 \times 10^{-}$

${ }^{8} \mathrm{~Pa}$ was maintained in the analysis chamber throughout experimentation. Data was collected by using the $\mathrm{Bi}^{1+}$ primary ion gun species operating in both the positive and negative polarity. ToF-SIMS ion intensity images of $256 \times 256$ pixels were acquired using a random raster, using spectroscopy mode over a $500 \times 500 \mu \mathrm{m}$ area on the sample surface. An electron flood gun was used to shower the sample with electrons to prevent a build-up of charge was operated at a filament current of $2.35 \mathrm{~A}$ during acquisition. Data acquisition, processing and analysis was performed using Surface Lab 6 (IONTOF, Germany).

\subsection{Results}

\subsection{Characterisation of the HA and SrHA Precursor Powders}

Figure 1(a) shows the XRD pattern for the HA powder, which is equivalent to that expected for pure HA in accordance with. the International Centre for Diffraction Data (ICDD) file \#00-09-0432. The peak positions signify that the material does not contain any additional impurity phases. The XRD pattern for the SrHA powder is shown in Figure 1(b) and is as expected for a Sr-substituted HA material, with broader peaks observed when compared to the pure HA powder, and shifting to lower $2 \theta$ positions. [36]. However, no additional impurities were detected using XRD for the SrHA material. 
Figure 2(a) shows a typical FTIR spectrum of the HA precursor powder. Absorption bands characteristic of $\mathrm{PO}_{4}{ }^{3-}$ stretching and bending vibrations can be observed between $1100-950 \mathrm{~cm}^{-1}$ and $620-450 \mathrm{~cm}^{-1}$ along with $\mathrm{O}-\mathrm{H}$ stretching and librational bands at 3570 and $632 \mathrm{~cm}^{-1}$, respectively as shown in Table 2 [29,36-38]. In addition to this, carbonate $\left(\mathrm{CO}_{3}{ }^{2-}\right)$ peaks were observed as highlighted in Table 2 [39]. These results show that the $\mathrm{HA}$ material exhibits $\mathrm{CO}_{3}{ }^{2-}$ substitution at both $\mathrm{OH}^{-}(\mathrm{A}-$ site $)$ and $\mathrm{PO}_{4}{ }^{3-}$ (B-site) locations [10,39]. Figure 2(b) and Table 2 highlights the FTIR results for the SrHA precursor powder. Poorly resolved peaks characteristic of $\mathrm{PO}_{4}{ }^{3-}$ groups can again be observed between $1100-950 \mathrm{~cm}^{-1}$ and $620-450 \mathrm{~cm}^{-1}$, as would be expected [40-43]. However, the peak expected for the O-H liberation at around 630 $\mathrm{cm}^{-1}$ is not present and the $\mathrm{O}-\mathrm{H}$ stretching vibration at $3569 \mathrm{~cm}^{-1}$ has a low intensity. Peaks associated with carbonate $\left(\mathrm{CO}_{3}{ }^{2-}\right)$ were also observed at $880 \mathrm{~cm}^{-1}$ and between $1550-1400 \mathrm{~cm}^{-1}$, which again highlights significant $\mathrm{CO}_{3}{ }^{2-}$ substitution in both the $\mathrm{A}$ and $\mathrm{B}$ sites [39].

Table 2. FTIR results from HA and SrHA powders.

\begin{tabular}{|c|c|c|}
\hline Peak Assignment & $\mathbf{H A}\left(\mathrm{cm}^{-1}\right)$ & $\operatorname{SrHA}\left(\mathrm{cm}^{-1}\right)$ \\
\hline \multirow{3}{*}{$\mathbf{P O}_{4}{ }^{3-}(\mathbf{P}-\mathrm{O})\left(\mathrm{v}_{3}\right)$} & 1091 & $1091 *$ \\
\hline & $1070^{*}$ & - \\
\hline & 1026 & $1025^{*}$ \\
\hline $\mathbf{P O}_{4}{ }^{3-}(\mathbf{P}-\mathrm{O})\left(v_{1}\right)$ & 962 & 961 \\
\hline \multirow{2}{*}{$\mathrm{PO}_{4}^{3-}(\mathrm{O}-\mathrm{P}-\mathrm{O})\left(\mathrm{U}_{4}\right)$} & 601 & 599 \\
\hline & 565 & 565 \\
\hline $\mathrm{PO}_{4}^{3-}(\mathrm{O}-\mathrm{P}-\mathrm{O})\left(\mathrm{v}_{2}\right)$ & 474 & 475 \\
\hline $\mathrm{CO}_{3}{ }^{2-}(\mathrm{C}-\mathrm{O})$ & $1550-1400$ & $1550-1400$ \\
\hline $\mathrm{CO}^{2-}(\mathrm{O}-\mathrm{C}-\mathrm{O})$ & 879 & 880 \\
\hline $\mathbf{O H}^{-}(\mathbf{O}-\mathbf{H})$ & 3570 & 3569 \\
\hline $\mathrm{OH}^{-}(\mathrm{O}-\mathrm{H})$ & 631 & - \\
\hline
\end{tabular}

The Raman spectra for the HA and SrHA precursor powders are shown in Figures 3(a) and (b), with their respective peak assignments in Table 3. The $\mathrm{PO}_{4}{ }^{3-}$ peak positions 
reported for the HA powder are all as expected for pure HA $[44,45]$ however, the peak positions that are reported for the SrHA powder are all shifted to lower values, which is typical of $\mathrm{Sr}$ substituted $\mathrm{HA}$ powders and the main $\mathrm{PO}_{4}{ }^{3-}$ at $956.2 \mathrm{~cm}^{-1}$ is considerably broader than that for pure $\mathrm{HA}[43,44] . \mathrm{CO}_{3}{ }^{2-}$ bands were not observed in the Raman spectra for either materials however, these may have been masked by the $\mathrm{PO}_{4}{ }^{3-}$ peaks.

Table 3. Raman results from HA and SrHA powders.

\begin{tabular}{ccc}
\hline Peak Designation & HA $\left(\mathbf{c m}^{-\mathbf{1}}\right)$ & SrHA $\left(\mathbf{c m}^{-\mathbf{1}}\right)$ \\
\hline PO $_{4}{ }^{3-}\left(\mathrm{v}_{2}\right)$ & 431.2 & 428.6 \\
& 448.8 & 445.0 \\
& 579.5 & 574.6 \\
$\mathbf{P O}_{4}{ }^{3-}\left(\mathrm{u}_{4}\right)$ & 590.6 & 586.9 \\
& 607.7 & 604.0 \\
$\mathbf{P O}_{4}{ }^{3-}\left(\mathrm{v}_{1}\right)$ & 616.3 & - \\
& 960.8 & 956.2 \\
$\mathbf{P O}_{4}{ }^{3-}\left(\mathrm{v}_{3}\right)$ & 1031.0 & 1027.6 \\
& 1045.6 & 1040.5 \\
& 1075.8 & 1070.2
\end{tabular}

Figure 4(a-d) shows the XPS peak-fitted high-resolution peaks for the C1s, O1s, Ca2p and P2p for the HA precursor powder. The corresponding peak positions for each of the individual components for the peak-fitting is given in Table 4, with the quantification results shown in Table 5. The peak positions match up to those expected for HA found in the literature [42,43]. For the C1s peak in Figure 4(a), the main component observed at $285.0 \mathrm{eV}$ was from C-H / C-C bonds present from surface hydrocarbons. The $\mathrm{C} 1 \mathrm{~s}$ components observed at 286.3, 287.8 and $289.3 \mathrm{eV}$, are indicative of $\mathrm{C}-\mathrm{H} / \mathrm{C}-\mathrm{C}, \mathrm{C}-\mathrm{O} / \mathrm{C}=\mathrm{O}$ and carbonate species, respectively [48-50]. Peakfitting the O1s envelope for the HA powder resulted in three components as shown in Figure 4(b). The components located at 531.7 and $532.9 \mathrm{eV}$ can be assigned to O-P and $\mathrm{O}-\mathrm{C}$ bonding, respectively [51]. The third additional component observed at 534.1 $\mathrm{eV}$ is associated with $\mathrm{O}=\mathrm{C}$ bonding or possibly physiosorbed water [51]. The $\mathrm{Ca} 2 \mathrm{p}$ envelope shows two doublets after peak-fitting, as seen in Figure 4(c). The Ca2 $\mathrm{p}_{1 / 2}$ and $\mathrm{Ca} 2 \mathrm{p}_{3 / 2}$ bands fitted to each of the resolved doublets are separated by $\sim 3.5 \mathrm{eV}$ and have the correct relative intensity ratio [38]. The most intense of these two overlapping 
doublets is present at $347.6 \mathrm{eV}\left(\mathrm{Ca} 2 \mathrm{p}_{3 / 2}\right)$ and $351.1 \mathrm{eV}\left(\mathrm{Ca} 2 \mathrm{p}_{1 / 2}\right)$ and the second lessintense doublet at $348.4 \mathrm{eV}\left(\mathrm{Ca} 2 \mathrm{p}_{3 / 2}\right)$ and $352.2 \mathrm{eV}\left(\mathrm{Ca} 2 \mathrm{p}_{1 / 2}\right)$. This data suggests that the calcium for the HA powder is present in two different chemical environments. The main doublet at lower binding energy is deemed to be associated with HA [38]. The most obvious source of the second, less intense, doublet is the occurrence of $\mathrm{CaCO}_{3}$ species. Additional support for this interpretation comes from the strong $\mathrm{CO}_{3}{ }^{2-}$ contribution to the corresponding $\mathrm{C} 1 \mathrm{~s}$ spectral envelope. However, the binding energy position for the $\mathrm{Ca} 2 \mathrm{p}_{3 / 2}$ line $(348.4 \mathrm{eV})$ is somewhat higher than that generally recorded in the literature for $\mathrm{CaCO}_{3}$, i.e. it is normally in the range $346.5-347.3 \mathrm{eV}$ [38]. Additionally, the presence of low concentrations of additional CaP phases cannot be ruled out [28]. Finally, for the HA precursor powder, as shown in Figure 4(d), the P2p envelope can be fitted with two peaks, one at $133.5 \mathrm{eV}$ and one at $134.4 \mathrm{eV}$. These can be attributed to the resolved doublet of P-O bonding from HA, with the peak at lower $\mathrm{BE}$ corresponding to the $\mathrm{P} 2 \mathrm{p}_{3 / 2}$ peak and the peak at higher $\mathrm{BE}$ corresponding to the $\mathrm{P} 2 \mathrm{p}_{1 / 2}$. The peaks are separated by $\sim 0.9 \mathrm{eV}$ and have the correct relative intensity ratio. The $\mathrm{Ca} / \mathrm{P}$ atomic ratio of the $\mathrm{HA}$ precursor powder was $1.59 \pm 0.02$, which is slightly lower than the value expected for stoichiometric HA (1.67), as shown in Table 5. This is not unexpected as XPS is a surface sensitive technique, analysing the top 5$10 \mathrm{~nm}$ of the sample. Similar results have been observed in the literature previously [27,28]. Figure 4(e-h) shows the peak-fitted high-resolution peaks for the C1s/Sr3p, $\mathrm{O} 1 \mathrm{~s}, \mathrm{Ca} 2 \mathrm{p}$ and $\mathrm{P} 2 \mathrm{p} / \mathrm{Sr} 3 \mathrm{~d}$ for the SrHA precursor powder. The corresponding peak positions for each of the individual components for the peak-fitting are given in Table 4, with the quantification results shown in Table 5.

The peak-fitting of the $\mathrm{C} 1 \mathrm{~s}$ and $\mathrm{O} 1 \mathrm{~s}$ envelopes showed distinct similarities to the those for the HA precursor powder, as highlighted in Table 4 and Figures 4(e) and (f), respectively. The Ca2p envelope for the SrHA precursor powder, as shown in Figure $4(\mathrm{~g})$ was fitted with a single doublet, with the $\mathrm{Ca} 2 \mathrm{p}_{3 / 2}(347.4 \mathrm{eV})$ and $\mathrm{Ca} 2 \mathrm{p}_{1 / 2}(350.9$ eV) bands separated by $\sim 3.5 \mathrm{eV}$ (and having the correct relative peak intensities) [38]. The envelope for P2p and Sr3d peaks overlaps significantly, as shown in Figure 4(h), but can be resolved into two distinct doublets. The first doublet represents P-O bonding from the SrHA, with the peak at lower binding energy (BE) corresponding to the $\mathrm{P} 2 \mathrm{p}_{3 / 2}$ peak $(133.1 \mathrm{eV})$, and the peak at higher $\mathrm{BE}$ corresponding to the $\mathrm{P} 2 \mathrm{p}_{1 / 2}$ $(133.9 \mathrm{eV})$. The peaks are separated by $\sim 0.8 \mathrm{eV}$ and have the correct relative intensity 
ratio. The second peak-fitted doublet represents the Sr3d peak, with the peak at lower binding energy $(\mathrm{BE})$ corresponding to the $\mathrm{Sr} 3 \mathrm{~d}_{5 / 2}$ peak $(133.3 \mathrm{eV})$ and the peak at higher BE corresponding to the $\mathrm{Sr}_{3} \mathrm{~d}_{3 / 2}(135.2 \mathrm{eV})$. The peaks are separated by $\sim 1.8$ $\mathrm{eV}$ and also have the correct relative intensity ratio [52]. Peak fitting of the P2p/Sr3d envelope in a $\mathrm{Sr}$ substituted HA powder has not been previously reported in the literature to the best of the knowledge of the authors. The $\mathrm{Ca} / \mathrm{P}$ ratio, $(\mathrm{Ca}+\mathrm{Sr}) / \mathrm{P}$ and $(\mathrm{Sr}+\mathrm{Ca}) / \mathrm{Sr}$ atomic ratios of the $\mathrm{SrHA}$ powder was $0.95 \pm 0.05,1.30 \pm 0.09$ and 1.37 \pm 0.03 , respectively as shown in Table 5 . These values were below those expected for this material [19].

Table 4. XPS peak positions from different powders and coatings (eV).

\begin{tabular}{|c|c|c|c|c|}
\hline Peak & HA Powder & SrHA Powder & HA Coating & SrHA Coating \\
\hline O1s & 531.7 & 531.2 & 531.4 & 531.4 \\
\hline O1s & 532.9 & 532.4 & 532.4 & 532.3 \\
\hline O1s & 534.1 & 533.6 & 533.8 & 533.3 \\
\hline $\mathrm{Ca} 2 \mathrm{p}_{3 / 2}$ & 347.6 & 347.4 & 347.4 & 347.7 \\
\hline $\mathbf{C a} 2 \mathbf{p}_{1 / 2}$ & 351.1 & 350.9 & 350.9 & 351.2 \\
\hline $\mathrm{Ca} 2 \mathbf{p}_{3 / 2}$ & 348.4 & - & 348.3 & - \\
\hline $\mathrm{Ca} 2 \mathbf{p}_{1 / 2}$ & 352.2 & - & 351.8 & - \\
\hline C1s & 285.0 & 285.0 & 285.0 & 285.0 \\
\hline C1s & 286.3 & 286.4 & 285.9 & 285.8 \\
\hline C1s & 287.8 & 287.8 & 286.7 & 286.5 \\
\hline C1s & 289.3 & 289.1 & 289.1 & 289.1 \\
\hline $\operatorname{Sr} 3 p_{3 / 2}$ & - & 269.1 & - & 269.6 \\
\hline $\operatorname{Sr} 3 p_{1 / 2}$ & - & 279.5 & - & 280.0 \\
\hline $\mathbf{P} 2 \mathrm{~s}$ & 191.0 & 190.8 & 190.8 & 190.8 \\
\hline $\mathbf{P} 2 \mathbf{p}_{3 / 2}$ & 133.5 & 133.1 & 133.2 & 133.3 \\
\hline $\mathbf{P} 2 \mathbf{p}_{1 / 2}$ & 134.4 & 133.9 & 134.1 & 134.2 \\
\hline $\operatorname{Sr} 3 d_{5 / 2}$ & - & 133.3 & - & 133.7 \\
\hline $\mathrm{Sr}_{3} d_{3 / 2}$ & - & 135.2 & - & 135.4 \\
\hline
\end{tabular}


Table 5. XPS data for the different HA and SrHA powders and coatings.

\begin{tabular}{|l|c|c|c|}
\hline \multirow{2}{*}{\multicolumn{1}{|c|}{ Sample }} & \multicolumn{3}{c|}{ Atomic \% Quantification Ratios } \\
\cline { 2 - 4 } & $\mathbf{C a} / \mathbf{P}$ & $(\mathbf{C a}+\mathbf{S r}) / \mathbf{P}$ & $(\mathbf{C a}+\mathbf{S r}) / \mathbf{C a}$ \\
\hline HA Powder & $1.59 \pm 0.02$ & - & - \\
\hline SrHA Powder & $0.95 \pm 0.05$ & $1.30 \pm 0.09$ & $1.37 \pm 0.03$ \\
\hline HA Coating & $1.81 \pm 0.02$ & - & - \\
\hline SrHA Coating & $1.18 \pm 0.05$ & $1.49 \pm 0.05$ & $1.26 \pm 0.01$ \\
\hline
\end{tabular}

ToF-SIMS has been used here to examine the surfaces of the pressed disks of the HA and SrHA powders. The positive ion spectra for the HA material is shown in Figure 5 (a) with the peaks observed at $\mathrm{m} / \mathrm{z}$ of 40,41 and 57 corresponding to $\mathrm{Ca}^{+}, \mathrm{CaH}^{+}$, and $\mathrm{CaOH}^{+}$, respectively [22,26,29]. A significant peak is also observed at $\mathrm{m} / \mathrm{z} 23$ in the HA powder positive ion spectrum, which corresponds to $\mathrm{Na}^{+}$. The positive ion spectra for the SrHA precursor is shown in Figure 5(c), with a strong $\mathrm{Sr}^{+}$peak clearly visible at $\mathrm{m} / \mathrm{z} 88$, as would have been expected [22]. For both the HA and SrHA powders the presence of a range of different isotopes and oxides of these species are also observed along with significant peaks corresponding to organic species. The negative ion spectra for the HA powder is shown in Figure 5(b), with strong peaks observed at $\mathrm{m} / \mathrm{z}$ of $16,17,47,63$ and 79 , corresponding to $\mathrm{O}^{-}, \mathrm{OH}^{-}, \mathrm{PO}^{-}, \mathrm{PO}_{2}^{-}$and $\mathrm{PO}_{3}^{-}$, respectively $[22,26,29]$. Peaks corresponding to organic contamination were detected throughout the spectrum along with peaks for $\mathrm{F}^{-}$and $\mathrm{Cl}^{-} \mathrm{m} / \mathrm{z}$ of 19 and 35 , respectively. The negative ion spectra obtained from the SrHA powder are largely similar to those for the HA powder as highlighted in Figure 5(d).

Normalised intensities of $\mathrm{Ca}^{+}, \mathrm{CaPO}_{2}{ }^{+}$and $\mathrm{Sr}^{+}$about the total ion count are presented in Figures 6(a) - positive ions and 6(b) - negative ions. The HA disk exhibited strong $\mathrm{Ca}^{+}$and $\mathrm{CaPO}_{2}{ }^{+}$with no intensity for $\mathrm{Sr}^{+}$. The SrHA disk exhibited a stronger peak $\mathrm{Ca}^{+}$and $\mathrm{CaPO}_{2}{ }^{+}$and a significant presence of $\mathrm{Sr}^{+}$. There are increases in the $\mathrm{PO}^{-}, \mathrm{PO}_{2}^{-}$ and $\mathrm{PO}_{3}{ }^{-}$intensity in the SrHA disk compared to the HA disk, as highlighted in Figure 8(b). For both the HA and SrHA disks, $\mathrm{PO}_{2}^{-}$had the strongest intensity. 
From these results the HA powder was confirmed to be a crystalline carbonated HA material. The SrHA powder analyses highlighted significant levels of Sr substituting for $\mathrm{Ca}$ in the $\mathrm{HA}$ lattice, with significant $\mathrm{A}-\mathrm{B} \mathrm{CO}_{3}{ }^{2-}$ substitution.

\subsection{Characterisation of the HA and SrHA Coatings}

The HA and SrHA coatings deposited here would be amorphous in nature due to the low discharge power utilised during RF magnetron sputtering, as has been shown in previous works by the authors [20-22]. Therefore, FTIR, Raman and XRD were not employed to analyse these surfaces as these results have been reported previously [2022]. Only XPS and ToF-SIMS were employed in this case to analyse the coatings in order to determine the chemistry of the uppermost surface, and in particular the spatial arrangement of functional groups of interest, namely $\mathrm{Sr}$.

Figure 7(a-d) shows the peak-fitted high-resolution peaks for the $\mathrm{C} 1 \mathrm{~s}, \mathrm{O} 1 \mathrm{~s}, \mathrm{Ca} 2 \mathrm{p}$ and P2p for the HA coating. The corresponding peak positions for each of the individual components for the peak-fitting is given in Table 4, with the quantification results shown in Table 5 correlate to those values anticipated for HA and are similar to those reported for the HA target powder $[38,42,40,48-51]$.

The $\mathrm{Ca} / \mathrm{P}$ ratio of the HA coating, as determined by XPS was $1.81 \pm 0.02$, which is higher than the value expected for stoichiometric HA (1.67), as shown in Table 5. Figure $7(\mathrm{e}-\mathrm{h}$ ) shows the peak-fitted high-resolution peaks for the $\mathrm{C} 1 \mathrm{~s} / \mathrm{Sr} 3 \mathrm{p}, \mathrm{O} 1 \mathrm{~s}, \mathrm{Ca} 2 \mathrm{p}$ and P2p/Sr3d for the SrHA coating. The corresponding peak positions for each of the individual components for the peak-fitting is given in Table 4, with the quantification results shown in Table 5. The peak-fitting for the C1s/Sr3p, O1s, Ca2p and P2p/Sr3d envelopes showed distinct similarities to the those for the SrHA precursor powder, as highlighted in Table 4 and Figures 7(e) and (f), respectively. Again, the peak fitting of the P2p/Sr3d peak envelope shows the presence of both the P2p and Sr3d doublets (similar to the SrHA precursor powder), which has not been reported in the literature to date (to the best of the knowledge of the authors). The $\mathrm{Ca} / \mathrm{P},(\mathrm{Ca}+\mathrm{Sr}) / \mathrm{P}$ and $\mathrm{Sr} /(\mathrm{Ca}$ $+\mathrm{Sr}$ ) ratios of the SrHA powder as determined by XPS were $1.18 \pm 0.05,1.49 \pm 0.05$ and $0.21 \pm 0.01$ respectively, as highlighted in Table 5. These values were below those 
expected but are in line with previous work in the area for such amorphous coatings $[21,22]$.

ToF-SIMS spectra of the titanium substrate Figure 8(a) and (b) show the surface is mainly dominated by $\mathrm{Na}^{+}$and $\mathrm{K}^{+}$at 23 and $39 \mathrm{~m} / \mathrm{z}$ respectively, alongside characteristic organic contamination. There is also a strong peak for $\mathrm{Ti}^{+}$at $48 \mathrm{~m} / \mathrm{z}$ and very weak peaks for $\mathrm{Ca}^{+}$and $\mathrm{CaPO}_{2}{ }^{+}$at 40 and $103 \mathrm{~m} / \mathrm{z}$ respectively, demonstrating that the titanium substrate sample has small amounts of calcium and calcium phosphate due to surface contamination. The negative titanium substrate spectra also exhibit surface contamination from typical organic species and dominating peaks of $\mathrm{O}^{-}$and $\mathrm{OH}^{-}$at 16 and $17 \mathrm{~m} / \mathrm{z}$, respectively, with no peaks present for $\mathrm{PO}^{-}, \mathrm{PO}_{2}{ }^{-}$or $\mathrm{PO}_{3}{ }^{-}$ . The HA coating shows dominant peaks of $\mathrm{Ca}^{+}$and $\mathrm{CaOH}^{+}$in the positive spectra and $\mathrm{PO}_{2}{ }^{-}$and $\mathrm{PO}_{3}{ }^{-}$in the negative spectra, there is also a small $\mathrm{CaPO}_{2}{ }^{+}$peak in the positive spectrum and $\mathrm{PO}^{-}$peak in the negative spectrum. The SrHA coating spectra strongly resembles the HA coating spectra with the exception of a strong $\mathrm{Sr}^{+}$peak being present in the positive polarity. These spectra show that the coating process has been effective with large amounts of calcium and phosphates present on the surface post-coating and that strontium has also been effectively sputtered. $\mathrm{No} \mathrm{Ti}^{+}$is present on positive polarity spectrum for either coating indicating that the coating has been deposited homogeneously.

Normalised intensities of $\mathrm{Ti}^{+}, \mathrm{Ca}^{+}, \mathrm{CaPO}_{2}{ }^{+}$and $\mathrm{Sr}^{+}$about the total ion count are presented in Figures 9(a) - positive ions and 9(b) - negative ions. The titanium surface exhibits none of the peaks related to the HA or SrHA coating, apart from a small amount of calcium contamination. The HA coating exhibited a significant increase in $\mathrm{Ca}^{+}$and $\mathrm{CaPO}_{2}^{+}$with virtually no intensity for $\mathrm{Ti}^{+}$and $\mathrm{Sr}^{+}$. The SrHA coating exhibited a lower presence of $\mathrm{Ca}^{+}$, the same amount of $\mathrm{CaPO}_{2}^{+}$and a significant presence of $\mathrm{Sr}^{+}$. The amount of $\mathrm{Sr}^{+}$and $\mathrm{Ca}^{+}$present in the SrHA coating is equal to the amount of $\mathrm{Ca}^{+}$present in the $\mathrm{HA}$ coating. There is a slight increase in $\mathrm{PO}_{2}{ }^{-}$and $\mathrm{PO}_{3}{ }^{-}$intensity in the SrHA coating compared to the HA coating, with no phosphate ions present on the surface of the uncoated titanium substrate, as highlighted in Figure 8(b). The positive polarity ion maps, as shown in Figure 10(a), for the titanium substrate show low levels of calcium contamination and almost no counts for the calcium phosphate or strontium ions, with strong ion counts for $\mathrm{Ti}^{+}$across the entire surface. Ion maps for the HA and SrHA coatings, as illustrated in Figures 10 (positive 
ion polarity maps) and 11 (negative ion polarity maps) show a homogenous distribution of $\mathrm{Ca}^{+}, \mathrm{CaPO}_{2}{ }^{+}, \mathrm{PO}^{-}, \mathrm{PO}_{2}{ }^{-}$and $\mathrm{PO}_{3}{ }^{-}$. ions across the surface and almost no $\mathrm{Ti}^{+}$counts. The SrHA coating shows a homogenous distribution of $\mathrm{Sr}^{+}$counts across the surface. This shows that both coatings are homogeneously deposited and that the substituted strontium is also evenly distributed across the surface, due to the random nature of the sputtering process. The negative polarity ion maps show no phosphate ions present on the titanium substrate surface and homogeneously distributed phosphate groups on the surface of the HA and SrHA coating.

\subsection{Discussion}

As highlighted earlier, the chemistry of these HA and SrHA coatings potentially offer significant benefits to cell behaviour in vitro and in vivo [22,53,54]. After sputtering these different materials onto the cpTi substrates distinct changes were observed in their surface properties as determined using XPS and ToF-SIMS analyses. The surface $\mathrm{Ca} / \mathrm{P}$ ratio of the thin films deposited from the HA targets was slightly higher than that expected for stoichiometric HA, at $1.81 \pm 0.02$ [21,22]. The positive ion spectrum ToF-SIMS results for the HA derived coating indicated the presence of other $\mathrm{Ca}$ species $\left(\mathrm{CaH}^{+}\right.$or $\left.\mathrm{CaOH}^{+}\right)$on the surface of the sample which may help in part to explain the slightly elevated $\mathrm{Ca} / \mathrm{P}$ ratio. This is also backed up by the presence of an additional $\mathrm{Ca} 2 \mathrm{p}$ doublet in the Ca2p XPS spectrum for the coating, indicating the presence of either a secondary $\mathrm{CaP}$ phase or $\mathrm{CaCO}_{3}$ material on the surface of the coating. However, this elevated $\mathrm{Ca} / \mathrm{P}$ is in line with expectations for coatings produced under the conditions employed here [21,22]. This may be a consequence of resputtering of the $\mathrm{P}$ species from the coating by negative $\mathrm{O}$ species as has been observed in previous work by Feddes at al [55]. Tyically this occurs at lower Ar gas pressures, and in the case here sputtering was undertaken at the lower end of the pressure range available in our sputtering system $(2 \mathrm{~Pa})$. It is further understood that this resputtering process can also be influenced by substrate biasing, however, substate biasing was not utilised in this study [56]. Furthermore, no $\mathrm{Sr}$ is detected on the surface of these $\mathrm{CaP}$ coatings prepared from the HA targets (as confirmed by both the XPS and ToF-SIMS results). The XPS analyses suggests that $\mathrm{CO}_{3}{ }^{2-}$ is present in the HA derived coatings given the $\mathrm{CO}_{3}{ }^{2-}$ peak observed at $289.1 \mathrm{eV}$ in the $\mathrm{C} 1$ s envelope, as shown in Figure 7(a). However, no distinctive $\mathrm{CO}_{3}{ }^{2-}$ peaks are observed in the ToF- 
SIMS spectra for this coating, suggesting that it is not present in the uppermost atomic layers of this sample. Therefore, the CaP coating deposited here could not be assigned a structural formula based on hydroxyapatite, or carbonated hydroxyapatite, as the coating deposited under the conditions employed here would be amorphous in nature $[30,31,57]$. It would therefore be better explained as a carbonated amorphous calcium phosphate material $\left[\mathrm{Ca}_{\mathrm{x}} \mathrm{H}_{\mathrm{y}}\left(\mathrm{PO}_{4}, \mathrm{CO}_{3}\right)_{\mathrm{z} . \mathrm{n}} \mathrm{H}_{2} \mathrm{O}\right.$ with a $\mathrm{Ca} / \mathrm{P}$ ratio of $\left.1.0-2.2\right]$ as described in previous reports in the literature, which may be more beneficial for stimulating the osteoblast response, rather than crystalline hydroxyapatite [1,58].

In comparison, the XPS results for the SrHA derived coatings were in line with expectations for a Sr-substituted HA like material. Peaks for $\operatorname{Sr} 3 \mathrm{p}_{3 / 2}$ and $\mathrm{Sr} 3 \mathrm{p}_{1 / 2}$ can be clearly observed at approximately 269.6 and $280.0 \mathrm{eV}$ in addition to the expected peaks for a $\mathrm{CaP}$ material $[21,22]$. The $\mathrm{Ca} / \mathrm{P}$ ratio (and corresponding $(\mathrm{Ca}+\mathrm{Sr}) / \mathrm{P}$ ratio) SrHA coatings were $1.18 \pm 0.05$ and $1.49 \pm 0.05$, respectively, as reported in Table 5 . Furthermore, if the $\mathrm{Sr} /(\mathrm{Ca}+\mathrm{Sr})$ ratios of the SrHA coating is compared to that of the SrHA precursor powder (as shown in Table 5) it is evident that the Sr levels within the SrHA derived coatings are significantly lower than that for the SrHA powder, which has been observed in previous studies, highlighting a lower sputtering yield for Sr ions when compared to $\mathrm{Ca}$, which may be related to the processing parameters utilised during sputtering. $[19,21,22]$. The processing history of the target could also play a role in this lower $\mathrm{Ca} / \mathrm{P}$ ratio, as has been highlighted previously by Surmenev et al [59]. The possibility that re-sputtering played a role in this low $\mathrm{Ca} / \mathrm{P}$ ratio cannot be ruled out either [55]. The presence of $\mathrm{Sr}$ on the uppermost surface of the coatings for the SrHA derived coatings is further confirmed by the ToF-SIMS analyses, as highlighted by the strong Sr peak at m/z 88 in Figures 8(e) and 9(a). Furthermore, the presence of $\mathrm{Sr}$ is seen to be homogenous and continuous across the surface, as highlighted by the positive ion maps in Figure 10. In addition, the ToF-SIMS result here show that $\mathrm{Ca}^{+}, \mathrm{PO}^{2-}$ and $\mathrm{PO}^{3-}$ species are more prevalent in the $\mathrm{HA}$ and SrHA coatings (compared with $\mathrm{CaPO}^{2-}$ and the $\mathrm{PO}^{-}$species) given the normalised ion intensities highlighted in Figure 6 (powders) and Figure 9 (coatings). This suggests preferential sputtering of $\mathrm{Ca}^{+}, \mathrm{PO}^{2-}$ and $\mathrm{PO}^{3-}$ fragments under the conditions employed in this study. Considering both the XPS and ToF-SIMS results obtained here, and the understanding that the coating is amorphous in nature (based on previous work involving Sr substituted HA coatings produced via sputtering) [21,22], the coatings 
would be best described as a strontium containing carbonated calcium phosphate material $\left[(\mathrm{Ca}, \mathrm{Sr})_{\mathrm{x}} \mathrm{H}_{\mathrm{y}}\left(\mathrm{PO}_{4}, \mathrm{CO}_{3}\right)_{\mathrm{z} . \mathrm{n}} \mathrm{H}_{2} \mathrm{O}\right]$. Consequently, the SrHA coating produced here could potentially provide enhanced benefits, both in vitro and in vivo, given it is both amorphous and contains appreciable levels of $\mathrm{Sr}$ ions on the uppermost surface of the coatings as shown by the surface characterisation undertaken here using XPS and ToF-SIMS.

\subsection{Conclusions}

The work reported here details the deposition of amorphous $\mathrm{CaP}$ and $\mathrm{Sr}$ containing $\mathrm{CaP}$ coatings via RF magnetron sputtering and their subsequent detailed characterisation using XPS and ToF-SIMS in order to better understand their uppermost surface chemistry. The HA and SrHA precursor powders used to deposit the coatings were both shown to be crystalline in nature and did not contain any significant levels of impurity phases. Both powders contained carbonate (with A-B substitution), as would have been expected, with the SrHA powder showing appreciable levels of $\mathrm{Sr}$, substituting for $\mathrm{Ca}$ in the $\mathrm{HA}$ lattice. The results for the coatings presented here clearly show that RF magnetron sputtering can deposit amorphous $\mathrm{CaP}$ and $\mathrm{Sr}$ containing $\mathrm{CaP}$ coatings, which are non-stoichiometric (when compared to HA) and contain carbonate groups. It is suggested that resputtering may influence the stoichiometry of the surfaces produced here. Also, the processing history of the targets may also be important and would merit further consideration in future. In addition to this, the surface characterisation employed here using XPS and ToFSIMS clearly show that the SrHA coating has Sr ions in the uppermost surface region in appreciable amounts, which are homogeneously distributed across the surface and commensurate with that required to deliver osteoconductive properties. These results highlight the importance of undertaking detailed surface characterisation of such coatings. However, these surfaces would need to be investigated by rigorous in vitro testing to provide further evidence of their potential bioactivity and utility as a suitable material for coatings in orthopaedic applications. 


\section{Acknowledgements}

The authors would like to acknowledge the $\mathrm{PhD}$ funding provided by the Department for the Economy (Northern Ireland). The authors would also like to thank the Meehan Family Scholarship, which facilitated part of the ToF-SIMS experiments.

\section{Data Availability}

The raw/processed data required to reproduce these findings cannot be shared at this time as the data also forms part of an ongoing study.

\section{References}

[1] A.S. Posner, F. Betts, Synthetic Amorphous Calcium Phosphate and Its Relation to Bone Mineral Structure, Acc. Chem. Res. 8 (1975) 273-281. doi:10.1021/ar50092a003.

[2] S. V Dorozhkin, M. Epple, Biological and Medical Significance of Calcium Phosphates, Angew. Chemie Int. Ed. 41 (2002) 3130-3146. doi:doi:10.1002/1521-3773(20020902)41:17<3130::AIDANIE3130>3.0.CO;2-1.

[3] E. Boanini, M. Gazzano, A. Bigi, Ionic substitutions in calcium phosphates synthesized at low temperature, Acta Biomater. 6 (2010) 1882-1894. doi:10.1016/j.actbio.2009.12.041.

[4] E. Landi, A. Tampieri, G. Celotti, S. Sprio, M. Sandri, G. Logroscino, Srsubstituted hydroxyapatites for osteoporotic bone replacement, Acta Biomater. 3 (2007) 961-969. doi:10.1016/j.actbio.2007.05.006.

[5] E. Gentleman, Y.C. Fredholm, G. Jell, N. Lotfibakhshaiesh, M.D. O'Donnell, R.G. Hill, M.M. Stevens, The effects of strontium-substituted bioactive glasses on osteoblasts and osteoclasts in vitro, Biomaterials. 31 (2010) 3949-3956. doi:10.1016/j.biomaterials.2010.01.121.

[6] N. Takahashi, T. Sasaki, Y. Tsouderos, T. Suda, S 12911-2 Inhibits Osteoclastic Bone Resorption In Vitro, J. Bone Miner. Res. 18 (2003) 1082-1087. doi:10.1359/jbmr.2003.18.6.1082.

[7] R. Baron, Y. Tsouderos, In vitro effects of S12911-2 on osteoclast function and bone marrow macrophage differentiation, Eur. J. Pharmacol. 450 (2002) 1117. doi:10.1016/S0014-2999(02)02040-X.

[8] E. Bonnelye, A. Chabadel, F. Saltel, P. Jurdic, Dual effect of strontium ranelate: Stimulation of osteoblast differentiation and inhibition of osteoclast formation and resorption in vitro, Bone. 42 (2008) 129-138. 
doi:10.1016/j.bone.2007.08.043.

[9] C. Capuccini, P. Torricelli, F. Sima, E. Boanini, C. Ristoscu, B. Bracci, G. Socol, M. Fini, I.N. Mihailescu, A. Bigi, Strontium-substituted hydroxyapatite coatings synthesized by pulsed-laser deposition: In vitro osteoblast and osteoclast response, Acta Biomater. 4 (2008) 1885-1893. doi:10.1016/j.actbio.2008.05.005.

[10] M. Kavitha, R. Subramanian, R. Narayanan, V. Udhayabanu, Solution combustion synthesis and characterization of strontium substituted hydroxyapatite nanocrystals, Powder Technol. 253 (2014) 129-137. doi:10.1016/j.powtec.2013.10.045.

[11] G.A. Fielding, M. Roy, A. Bandyopadhyay, S. Bose, Antibacterial and biological characteristics of silver containing and strontium doped plasma sprayed hydroxyapatite coatings, Acta Biomater. 8 (2012) 3144-3152. doi:10.1016/j.actbio.2012.04.004.

[12] T. Huang, Y. Xiao, S. Wang, Y. Huang, X. Liu, F. Wu, Z. Gu, Nanostructured $\mathrm{Si}, \mathrm{Mg}, \mathrm{CO} 32$ - substituted hydroxyapatite coatings deposited by liquid precursor plasma spraying: Synthesis and characterization, J. Therm. Spray Technol. 20 (2011) 829-836. doi:10.1007/s11666-011-9628-y.

[13] W. Xue, H.L. Hosick, A. Bandyopadhyay, S. Bose, C. Ding, K.D.K. Luk, K.M.C. Cheung, W.W. Lu, Preparation and cell-materials interactions of plasma sprayed strontium-containing hydroxyapatite coating, Surf. Coatings Technol. 201 (2007) 4685-4693. doi:10.1016/j.surfcoat.2006.10.012.

[14] A. Balamurugan, G. Balossier, P. Torres, J. Michel, J.M.F. Ferreira, Sol-gel synthesis and spectrometric structural evaluation of strontium substituted hydroxyapatite, Mater. Sci. Eng. C. 29 (2009) 1006-1009. doi:10.1016/j.msec.2008.09.005.

[15] C. O'Sullivan, P. O'Hare, N.D. O'Leary, A.M. Crean, K. Ryan, A.D.W. Dobson, L. O'Neill, Deposition of substituted apatites with anticolonizing properties onto titanium surfaces using a novel blasting process, J. Biomed. Mater. Res. - Part B Appl. Biomater. 95 (2010) 141-149. doi:10.1002/jbm.b.31694.

[16] E. Boanini, P. Torricelli, M. Fini, F. Sima, N. Serban, I.N. Mihailescu, A. Bigi, Magnesium and strontium doped octacalcium phosphate thin films by matrix assisted pulsed laser evaporation, J. Inorg. Biochem. 107 (2012) 65-72. doi:10.1016/j.jinorgbio.2011.11.003.

[17] C.J. Chung, H.Y. Long, Systematic strontium substitution in hydroxyapatite coatings on titanium via micro-arc treatment and their osteoblast/osteoclast responses, Acta Biomater. 7 (2011) 4081-4087. doi:10.1016/j.actbio.2011.07.004.

[18] P. O’Hare, B.J. Meenan, G.A. Burke, G. Byrne, D. Dowling, J.A. Hunt, Biological responses to hydroxyapatite surfaces deposited via a co-incident microblasting technique, Biomaterials. $31 \quad$ (2010) 515-522. doi:https://doi.org/10.1016/j.biomaterials.2009.09.067.

[19] K. Ozeki, T. Hoshino, H. Aoki, T. Masuzawa, Phase Composition of Sputtered 
Film from a Mixture Target of Hydroxyapatite and Strontium-apatite, J. Mater. Sci. Technol. 29 (2013) 1-6. doi:10.1016/j.jmst.2012.11.014.

[20] L. Robinson, K. Salma-Ancane, L. Stipniece, B.J. Meenan, A.R. Boyd, The deposition of strontium and zinc Co-substituted hydroxyapatite coatings, J. Mater. Sci. Mater. Med. 28 (2017). doi:10.1007/s10856-017-5846-2.

[21] A.R. Boyd, L. Rutledge, L.D. Randolph, B.J. Meenan, Strontium-substituted hydroxyapatite coatings deposited via a co-deposition sputter technique, Mater. Sci. Eng. C. 46 (2015) 290-300. doi:10.1016/j.msec.2014.10.046.

[22] A.R. Boyd, L. Rutledge, L.D. Randolph, I. Mutreja, B.J. Meenan, The deposition of strontium-substituted hydroxyapatite coatings, J. Mater. Sci. Mater. Med. 26 (2015) 1-14. doi:10.1007/s10856-014-5377-z.

[23] K.A. Prosolov, K.S. Popova, O.A. Belyavskaya, J.V. Rau, K.A. Gross, A. Ubelis, Yu.P. Sharkeev, RF magnetron-sputtered coatings deposited from biphasic calcium phosphate targets for biomedical implant applications, Bioactive Materials, 2017, 2, 170-176.

[24] K.A. Prosolov, V.V. Lastovka, O.A. Belyavskaya, D.V. Lychagin, J Schmidt, Y.P. Sharkeev, Tailoring the Surface Morphology and the Crystallinity State of $\mathrm{Cu}-$ and Zn-Substituted Hydroxyapatites on $\mathrm{Ti}$ and $\mathrm{Mg}$-Based Alloys. Materials 13, 2020, 4449.

[25] A.A. Ivanova, M.A. Surmeneva, R.A. Surmenev, D. Depla, Structural evolution and growth mechanisms of RF-magnetron sputter-deposited hydroxyapatite thin films on the basis of unified principles. Applied Surface Science, 425, 2017, 497-506.

[26] S.R. Leadley, M.C. Davies, C. Castro Ribeiro, M.A. Barbosa, A.J. Paul, J.F. Watts, Investigation of the dissolution of the bioceramic hydroxyapatite in the presence of titanium ions using ToF-SIMS and XPS, Biomaterials. 18 (1997) 311-316. doi:10.1016/S0142-9612(96)00134-2.

[27] H.B. Lu, C.T. Campbell, D.J. Graham, B.D. Ratner, Surface characterization of hydroxyapatite and related calcium phosphates by XPS and TOF-SIMS, Anal. Chem. 72 (2000) 2886-2894. doi:10.1021/ac990812h.

[28] C.C. Chusuei, Calcium phosphate phase identification using XPS and time-offlight cluster SIMS, Anal. Chem. 71 (1999) 149-153. doi:10.1021/ac9806963.

[29] W. Xia, C. Lindahl, J. Lausmaa, P. Borchardt, A. Ballo, P. Thomsen, H. Engqvist, Biomineralized strontium-substituted apatite/titanium dioxide coating on titanium surfaces, Acta Biomater. 6 (2010) 1591-1600. doi:10.1016/j.actbio.2009.10.030.

[30] A.R. Boyd, H. Duffy, R. McCann, M.L. Cairns, B.J. Meenan, The Influence of argon gas pressure on co-sputtered calcium phosphate thin films, Nucl. Instruments Methods Phys. Res. Sect. B Beam Interact. with Mater. Atoms. 258 (2007) 421-428. doi:10.1016/j.nimb.2007.02.072.

[31] A.R. Boyd, G.A. Burke, H. Duffy, M. Holmberg, C. O’Kane, B.J. Meenan, P. Kingshott, Sputter deposited bioceramic coatings: Surface characterisation and initial protein adsorption studies using surface-MALDI-MS, J. Mater. Sci. 
Mater. Med. 22 (2011) 74-84. doi:10.1007/s10856-010-4180-8.

[32] A.R. Boyd, C. O'Kane, B.J. Meenan, Control of calcium phosphate thin film stoichiometry using multi-target sputter deposition, Surf. Coatings Technol. 233 (2013) 131-139. doi:https://doi.org/10.1016/j.surfcoat.2013.04.017.

[33] J.G. Acheson, S. McKillop, P. Lemoine, A.R. Boyd, B.J. Meenan, Control of magnesium alloy corrosion by bioactive calcium phosphate coating: Implications for resorbable orthopaedic implants, Materialia. 6 (2019) 10. doi:10.1016/j.mtla.2019.100291.

[34] C. Combes, C. Rey, Amorphous calcium phosphates: Synthesis, properties and uses in biomaterials, Acta Biomater. 6 (2010) 3362-3378. doi:10.1016/j.actbio.2010.02.017.

[35] ASTM International, Standard Guide to Charge Control and Charge Referencing Techniques in X-Ray Photoelectron Spectroscopy, (2015).

[36] A.R. Boyd, B.J. Meenan, N.S. Leyland, Surface characterisation of the evolving nature of radio frequency (RF) magnetron sputter deposited calcium phosphate thin films after exposure to physiological solution, Surf. Coatings Technol. 200 (2006) 6002-6013. doi:10.1016/j.surfcoat.2005.09.032.

[37] A.R. Boyd, H. Duffy, R. McCann, B.J. Meenan, Sputter deposition of calcium phosphate/titanium dioxide hybrid thin films, Mater. Sci. Eng. C. 28 (2008) 228-236. doi:10.1016/j.msec.2006.12.004.

[38] A. Boyd, M. Akay, B.J. Meenan, Influence of target surface degradation on the properties of r.f. Magnetron-sputtered calcium phosphate coatings, Surf. Interface Anal. 35 (2003) 188-198. doi:10.1002/sia.1512.

[39] I.R. Gibson, W. Bonfield, Novel synthesis and characterization of an AB-type carbonate-substituted hydroxyapatite, J. Biomed. Mater. Res. 59 (2002) 697708. doi:10.1002/jbm.10044.

[40] S. Koutsopoulos, Synthesis and characterization of hydroxyapatite crystals: A review study on the analytical methods, J. Biomed. Mater. Res. 62 (2002) 600612. doi:10.1002/jbm.10280.

[41] F. García, J.L. Arias, B. Mayor, J. Pou, I. Rehman, J. Knowles, S. Best, B. León, M. Pérez-Amor, W. Bonfield, Effect of heat treatment on pulsed laser deposited amorphous calcium phosphate coatings, J. Biomed. Mater. Res. 43 (1998) 6976. doi:10.1002/(SICI)1097-4636(199821)43:1<69::AID-JBM8>3.0.CO;2-K.

[42] N. Lowry, M. Brolly, Y. Han, S. McKillop, B.J. Meenan, A.R. Boyd, Synthesis and characterisation of nanophase hydroxyapatite co-substituted with strontium and zinc, Ceram. Int. 44 (2018) 7761-7770. doi:10.1016/j.ceramint.2018.01.206.

[43] N. Lowry, Y. Han, B.J. Meenan, A.R. Boyd, Strontium and zinc co-substituted nanophase hydroxyapatite, Ceram. Int. 43 (2017) 12070-12078. doi:10.1016/j.ceramint.2017.06.062.

[44] V. Aina, L. Bergandi, G. Lusvardi, G. Malavasi, F.E. Imrie, I.R. Gibson, G. Cerrato, D. Ghigo, Sr-containing hydroxyapatite: Morphologies of HA crystals and bioactivity on osteoblast cells, Mater. Sci. Eng. C. 33 (2013) 1132-1142. 
doi:10.1016/j.msec.2012.12.005.

[45] J.A. Stammeier, B. Purgstaller, D. Hippler, V. Mavromatis, M. Dietzel, In-situ Raman spectroscopy of amorphous calcium phosphate to crystalline hydroxyapatite transformation, MethodsX. 5 (2018) 1241-1250. doi:10.1016/j.mex.2018.09.015.

[46] G. Cheng, Y. Zhang, H. Yin, Y. Ruan, Y. Sun, K. Lin, Effects of strontium substitution on the structural distortion of hydroxyapatite by rietveld refinement and Raman Spectroscopy, Ceram. Int. 45 (2019) 11073-11078. doi:10.1016/j.ceramint.2019.02.194.

[47] P. Nandha Kumar, S.K. Mishra, R. Udhay Kiran, S. Kannan, Preferential occupancy of strontium in the hydroxyapatite lattice in biphasic mixtures formed from non-stoichiometric calcium apatites, Dalt. Trans. 44 (2015) 82848292. doi:10.1039/c5dt00173k.

[48] S.W. Ha, M. Kirch, F. Birchler, K.L. Eckert, J. Mayer, E. Wintermantel, C. Sittig, I. Pfund-Klingenfuss, M. Textor, N.D. Spencer, M. Guecheva, H. Vonmont, Surface activation of polyetheretherketone (PEEK) and formation of calcium phosphate coatings by precipitation, J. Mater. Sci. Mater. Med. 8 (1997) 683-690. doi:10.1023/A:1018535923173.

[49] J.L. Ong, C.A. Hoppe, H.L. Cardenas, R. Cavin, D.L. Carnes, A. Sogal, G.N. Raikar, Osteoblast precursor cell activity on HA surfaces of different treatments, J. Biomed. Mater. Res. 39 (1998) 176-183. doi:10.1002/(SICI)1097-4636(199802)39:2<176::AID-JBM2>3.0.CO;2-M.

[50] J.L. Ong, L.C. Lucas, G.N. Raikar, J.J. Weimer, J.C. Gregory, Surface characterization of ion-beam sputter-deposited Ca-P coatings after in vitro immersion, Colloids Surfaces A Physicochem. Eng. Asp. 87 (1994) 151-162. doi:https://doi.org/10.1016/0927-7757(94)02774-9.

[51] A.R. Boyd, C. O'Kane, P. O'Hare, G.A. Burke, B.J. Meenan, The influence of target stoichiometry on early cell adhesion of co-sputtered calcium-phosphate surfaces, J. Mater. Sci. Mater. Med. 24 (2013) 2845-2861. doi:10.1007/s10856013-5021-3.

[52] I. S, A. C, Functionalization of Nanostructured TiO2 Surfaces with Electrodeposited Strontium Doped Calcium Phosphate and Evaluation of BSA Adsorption for Dental Implant Design, J. Nanomed. Nanotechnol. 06 (2016). doi:10.4172/2157-7439.1000343.

[53] M. Roy, G. a. Fielding, A. Bandyopadhyay, S. Bose, Effects of zinc and strontium substitution in tricalcium phosphate on osteoclast differentiation and resorption, Biomater. Sci. (2013) 74-82. doi:10.1039/c2bm00012a.

[54] F. Yang, D. Yang, J. Tu, Q. Zheng, L. Cai, L. Wang, Strontium enhances osteogenic differentiation of mesenchymal stem cells and in vivo bone formation by activating Wnt/catenin signaling, Stem Cells. (2011). doi:10.1002/stem.646.

[55] B. Feddes, J. G. C. Wolke, and J. A. Jansen, Radio frequency magnetron sputtering deposition of calcium phosphate coatings: The effect of resputtering on the coating composition, J Appl Physics 93 (2003), 9503-9507. 
https://doi.org/10.1063/1.1576894

[56] M. A. Surmeneva, A. Kovtun, A. Peetsch, S. N. Gorojaa A. A. Sharonova, V. F. Pichugin, I. Y. Grubova, A. A. Ivanova, A. D. Teresov, N. N. Koval, V. Buck, A. Wittmar, M. Ulbricht, O. Prymak, M. Epple and R. A. Surmenev. Preparation of a silicate-containing hydroxyapatitebased coating by magnetron sputtering: structure and osteoblast-like MG63 cells in vitro study, RSC Advances, 3, 2013, 11240. DOI: 10.1039/c3ra40446c

[57] A.R. Boyd, C. O'Kane, B.J. Meenan, Control of calcium phosphate thin film stoichiometry using multi-target sputter deposition, Surf. Coatings Technol. 233 (2013) 131-139. doi:https://doi.org/10.1016/j.surfcoat.2013.04.017.

[58] D. Tadic, F. Peters, M. Epple, Continuous synthesis of amorphous carbonated apatites, Biomaterials. 23, 2002, 2553-2559. doi:10.1016/S01429612(01)00390-8.

[59] R. A. Surmenev, A review of plasma-assisted methods for calcium phosphatebased coatings fabrication, Surf Coat Tech, 206 (2012) 2035-2056. doi:10.1016/j.surfcoat.2011.11.002

\section{Figure Captions:}


Figure 1. XRD patterns for (a) HA powder, (b) SrHA powder, (") refers to ICCD \# 090432 .

Figure 2. FTIR Spectra for (a) HA powder, (b) SrHA powder.

Figure 3. Raman Spectra for (a) HA powder, (b) SrHA powder.

Figure 4. XPS high resolution scans for (a) C1s HA powder, (b) O1s HA powder, (c) Ca2p HA powder, (d) P2p HA powder, (e) C1s/Sr3p SrHA powder, (f) O1s SrHA powder, (g) Ca2p SrHA powder and (h) P2p/Sr3d SrHA powder.

Figure 5. ToF-SIMS spectra (a) positive ions HA powder, (b) positive ions SrHA powder, (c) negative ions HA powder and (d) negative ions SrHA powder.

Figure 6. Normalised ion intensities of HA and SrHA disks obtained from ToF-SIMS spectra for (a) positive ions and (b) for negative ions.

Figure 7. XPS High resolution scans for (a) C1s HA coating, (b) O1s HA coating, (c) Ca2p HA coating, (d) P2p HA coating, (e) C1s/Sr3p SrHA coating, (f) O1s SrHA coating, (g) Ca2p SrHA coating and (h) P2p/Sr3d SrHA coating.

Figure 8. ToF-SIMS spectra positive (Left) and negative (Right) of $(a, b)$ titanium substrate, (c,d) HA coating, (e,f) SrHA coating.

Figure 9. Normalised ion intensities of HA and SrHA coatings obtained from ToF-SIMS spectra for (a) positive ions and (b) for negative ions.

Figure 10. ToF-SIMS positive ion maps of total ion count (TIC), $\mathrm{Ca}^{+}, \mathrm{CaPO}_{2}{ }^{+}, \mathrm{Sr}^{+}$and $\mathrm{Ti}^{+}$for (a-e) titanium substrate, (f-j) HA coating and (k-o) SrHA coatings.

Figure 11. ToF-SIMS negative ion maps of total ion count (TIC), $\mathrm{Ca}^{+}, \mathrm{PO}_{2}{ }^{+}, \mathrm{Sr}^{+}$and $\mathrm{Ti}^{+}$ for (a-d) titanium substrate, (e-h) HA coating and (i-l) SrHA coatings. 